\title{
UPAYA MENINGKATKAN SIKAP PEDULI LINGKUNGAN DAN PRESTASI BELAJAR MENGGUNAKAN MODEL CTL (CONTEXTUAL TEACHING AND LEARNING)PADA TEMA 7 INDAHNYA KERAGAMAN DI NEGERIKU KELAS IV MI MUHAMMADIYAH LIMBANGAN
}

\author{
Lulu Dwi Lestari ${ }^{1}$, Karma Iswasta Eka ${ }^{2}$, Okto Wijayanti ${ }^{3}$ \\ 1,2,3 PGSD, Universitas Muhammadiyah Purwokerto \\ Corresponding Email: ${ }^{1}$ luludwi3@gmail.com,
}

\begin{abstract}
ABSTRAK
Penelitian ini bertujuan untuk mengetahui peningkatan sikap peduli lingkungan dan prestasi belajar dengan model model CTL (contextual teaching and learning) pada tema 7 indahnya keragaman di negeriku kelas IV A MI Muhammadiyah Limbangan. Jenis penelitian ini menggunakan Penelitian Tindakan Kelas (PTK) yang dilakukan dalam 2 siklus. Subjek penelitian berjumlah 21 peserta didik. Data yang dikumpulkan adalah sikap peduli lingkungan dan prestasi belajar peserta didik. Hasil penelitian menunjukkan bahwa: Pertama, penerapan model CTL (contextual teaching and learning) dapat meningkatkan sikap peduli lingkungan peserta didik dilihat dari perolehan persentase klasikal angket siklus I yaitu $71 \%$ dan rata-rata 1,5 dengan kriteria cukup yang mengalami peningkatan menjadi $87 \%$ dan rata-rata 1,7 dengan kriteria baik di siklus II. Kedua, penerapan model CTL (contextual teaching and learning) dapat meningkatkan prestasi belajar peserta didik dilihat dari perolehan rata-rata nilai siklus I yaitu 71 dengan ketuntasan belajar $72 \%$ dan meningkat menjadi 75 dengan ketuntasan belajar $81 \%$ pada siklus II sehingga indikator keberhasilan penelitian tercapai.
\end{abstract}

Kata kunci: Sikap peduli lingkungan, prestasi belajar, model CTL (contextual teaching and learning) .

\begin{abstract}
This research aims to identify the improvement of environmental care attitude and learning achievement throughCTL model on theme 7 about the beauty of diversity in my country in grade IV A MI Muhammadiyah Limbangan. It is a classroom action research (CAR) conducted within 2 cycles. The research subjects are 21 students. Thecollected data consist of students' environmental care attitude and learning achievement. The research result indicates that: First, the implementation of CTL (Contextual Teaching and Learning) is able to improve the students' environmental care attitude. This is seen from the result of the cycle I questionnaire classical percentage of $71 \%$ and an average of 1.5 with fair criteria. The result improves to $87 \%$ and an average of 1.7 with good criteria in cycle II. Second, the implementation of CTL is able to improve the students learning achievement. This can be seen from the result of the students' average score in cycle I, which is 71 with mastery learning of $72 \%$, improves
\end{abstract}


to 75 with the mastery learning of $81 \%$ in cycle II. Thus, the success indicator of the research is achieved.

Keywords: environmental care attitude, learning achievement, CTL (contextual teaching and learning) model 


\section{PENDAHULUAN}

Manusia dan lingkungan memiliki hubungan berkaitan satu sama lain dan tidak dapat dipisahkan. Perilaku manusia dalam kehidupan sehari-hari sangat mempengaruhi lingkungan alam sekitar yang tidak. Manusia sangat bergantung pada lingkungan yang memberikan sumber daya alam untuk tetap bertahan hidup. Manusia perlu dibentuk agar sadar akan pentingnya lingkungan bagi kehidupan, maka perlu usaha yang dapat membina, mengarahkan dan menjadikan seseorang mempunyai jiwa mencintai lingkungan hidup. Oleh karena itu, sikap peduli lingkungan perlu ditanamkan sejak dini melalui pendidikan. Sekolah merupakan lembaga pendidikan yang dapat membina karakter peduli lingkungan karena pada dasarnya menjaga dan melestarikan lingkungan alam merupakan tanggung jawab semua manusia.

Lingkungan sekolah yang dijaga dan dilestarikan kebersihannya sangat penting untuk kemajuan sekolah. Sekolah yang bersih akan menciptakan proses belajar mengajar menjadi baik, sebaliknya jika lingkungan sekolah kotor maka akan menimbulkan dampak negatif, sehingga kegiatan belajar mengajar pun menjadi terganggu, sehingga peserta didik menjadi malas dalam belajar serta sulit menerima pelajaran yang disampaikan oleh guru. Kegiatan belajar mengajar di kelas juga perlu di dukung dengan lingkungan yang bersih sehingga dapat memberikan kepamahaman peserta didik akan pentingnya menanamkan kebersihan dilingkungan sekolah sebagai bentuk tanggung jawab seluruh warga sekolah agar terciptanya suasana yang kondusif aman dan nyaman dalam proses belajar mengajar.

Berdasarkan hasil observasi dan wawancara dengan guru kelas IV MI Muhammadiyah Limbangan diperoleh data bahwa peserta didik kelas IV A belum mampu menanamkan sikap peduli lingkungan dalam diri. Hal tersebut terlihat dalam keseharian peserta didik dalam penghematan energi listrik masih kurang diperhatikan seperti pada siang hari lampu dibiarkan menyala. Peserta didik pun masih membuang sampah sembarangan, sampah banyak ditemukan di laci-laci meja dalam kelas, dan peserta didik sering memanfaatkan kertas yang tidak sesuai untuk diperuntukkan seperti membuat mainan. Perilaku membuang sampah tersebut didorong belum tersedianya tempat sampah yang terpisah. Fasilitas untuk mendaur ulang atau mengolah sampah pun belum tersedia.

Sikap peduli lingkungan bukan hanya menjadi salah satu masalah yang ada, namun prestasi belajar peserta didik di kelas IV MI Muhammadiyah Limbangan juga masih rendah. Hal ini dapat ditunjukkan dengan perolehan hasil belajar peserta didik pada Ulangan Harian pada mata pelajaran IPA yang kurang maksimal, dan tidak mencapai Kriteria Ketuntasan Minimal (KKM) yang telah ditentukan. Perolehan dari jumlah peserta didik 21 orang,yang 329 | JURNAL IKA VOL 8 No. 2 DESEMBER 2020 
mencapai ketuntasan hanya hanya 13 orang dengan persentase $61 \%$ dan tidak mencapai ketuntasan yaitu 8 orang dengan persentase 39\%. Ketuntasan tersebut dilihat dari KKM yang ditentukan oleh guru kelas tersebut, yaitu 70. Hal tersebut menunjukkan perlu diperbaiki agar tidak menjadi permasalahan dalam hasil prestasi belajar.

Salah satu model pembelajaran yang dapat meningkatkan sikap peduli lingkungan dan prestasi belajar pada peserta didik pada mata pelajaran Ilmu Pengetahuan Alam adalah Contextual Teaching And Learning (CTL). Pembelajaran CTL menurut Suyadi (2013: 81) menekankan pada proses keterlibatan peserta didik dalam menemukan hubungan antara materi dengan realitas kehidupan, sehingga mendorong peserta didik memperoleh informasi dan pemahaman yang lebih terhadap lingkungan.

Upaya dalam mewujudkan sikap peduli lingkungan salah satunya dengan proses pembelajaran yang mengarahkan peserta didik dapat mengembangkan pengetahuan, dan keterampilan dalam memecahkan permasalahan lingkungan. Penerapan model pembelajaran CTL diharapkan dapat meningkatkan sikap peduli lingkungan dan prestasi belajar peserta didik. Berdasarkan uraian tersebut, peneliti akan melakukan Penelitian Tindakan Kelas (PTK) dengan judul Upaya Meningkatkan Sikap Peduli Lingkungan Dan Prestasi Belajar Menggunakan Model CTL (Contextual Teaching And Learning) Pada Tema 7 Indahnya Keragaman Di Negeriku kelas IV MI Muhammadiyah Limbangan.

\section{METODE PENELITIAN}

Penelitian tindakan ini termasuk dalam penelitian tindakan kelas ( action research) yang dilakukan oleh guru sekaligus sebagai peneliti di kelasnya atau bersama-sama dengan orang lain (kolaborasi) dengan jalan merancang, melaksanakan dan merefleksi tindakan secara kolaboratif serta partisipatif yang bertujuan untuk memperbaiki atau meningkatkan kualitas proses pembelajaran di kelas melalui suatu tindakan tertentu dalam suatu siklus. Penelitian tindakan kelas ini peneliti menggunakan model Kemmis dan Mc Taggart yang terdiri dari siklus-siklus. Dalam penelitian tindakan kelas model Kemmis dan Mc Taggart terdiri dari 4 tahapan penting, yakni perencanaan (planning), pelaksanaan tindakan (action), observasi (observation), dan refleksi (reflecting). Subjek Penelitian Tindakan Kelas ini yaitu peserta didik kelas IV MI Muhammadiyah Limbangan, Kecamatan Kutasari, Kabupaten Purbalingga. Jumlah keseluruhan 21 peserta didik yang terdiri dari 13 peserta didik laki-laki dan 8 peserta didik perempuan.

\section{Instrumen dan Pengumpulan Data}

330 | JURNAL IKA VOL 8 No. 2 DESEMBER 2020 
Teknik yang digunakan untuk mengumpulkan data yaitu tes dan non tes.

Tes Tertulis

Pada penelitian ini, tes digunakan untuk mengukur prestasi belajar peserta didik pada mata pelajaran IPA dengan model CTL Jenis tes yang digunakan pada penelitian ini adalah tes tertulis yang dapat mengukur keberhasilan dalam proses pembelajaran. Tes berupa soal uraian yang akan dibagikan pada setiap akhir pertemuan.

Lembar Angket

Pada penelitian ini angket yang akan digunakan angket dengan skala Ghuttman. Lembar angket digunakan untuk mengukur aspek sikap peduli lingkungan. Lembar angket berisi pertanyaan-pertanyaan yang harus diisi dan jawab oleh peserta didik.

Lembar Observasi

Pada penelitian ini lembar observasi digunakan untuk mendapatkan data pengamatan peserta didik dan aktivitas guru saat pembelajaran. lembar ini menggunakan skala Likert.

\section{Teknik Analisis Data}

Pada penelitian ini akan digunakan teknik analisis data kualitatif dan kuantitatif. Analisis data kuantitatif dalam bentuk angka-angka, terdiri dari prestasi belajar, lembar angket sikap peduli lingkungan, lembar aktivitas Guru dan Peserta Didik. Analisis kualitatif digunakan untuk menganalisis data dari hasil observasi guru dan peserta didik pembentukan sikap peduli lingkungan dalam proses pembelajaran. Menganalisis prestasi belajar dengan menghitung nilai rata-rata setiap peserta didik di akhir siklus.

\section{Analisis Evaluasi Belajar Peserta Didik}

\section{Nilai Peserta Didik}

Nilai $=\frac{\text { skor mentah }}{\text { skor maksimum idal }} \times 100$

(Purwanto, 2010:102)

\section{Rata-rata kelas}

$\bar{X}=\frac{\sum x}{N}$

Keterangan :

$\bar{X} \quad$ : Nilai rata-rata

$\sum \mathrm{X} \quad$ : Jumlah seluruh skor

331 | JURNAL IKA VOL 8 No. 2 DESEMBER 2020 
$N \quad$ : Banyaknya subjek

(Sudjana, 2011:109)

Adapun tentang penggolongan nilai akhir sebagai berikut:

$\begin{array}{ll}81-100 \% & : \text { Sangat Baik } \\ 61-80 \% & \text { : Baik } \\ 41-60 \% & \text { : Cukup } \\ 21-40 \% & \text { : Kurang } \\ \leq 20 \% & \text { : Kurang Sekali }\end{array}$

(Arikunto \& Jabar, 2010:35)

\section{Ketuntasan Belajar Peserta Didik}

Untuk menghitung ketuntasan belajar peserta didik yaitu dengan menggunakan rumus sebagai berikut:

$\mathrm{P}=\frac{F}{N} \times 100$

Keterangan:

P : Persentase Ketuntasan Belajar

F : Jumlah peserta didik yang tuntas belajar

$\mathrm{N} \quad$ : Jumlah seluruh peserta didik

(Djamarah, 2010:264)

Penggolongan rentang ketuntasan belajar peserta didik adalah sebagai berikut:

$$
\begin{array}{ll}
81-100 \% & \text { : Sangat Baik } \\
61-80 \% & : \text { Baik } \\
41-60 \% & \text { : Cukup } \\
21-40 \% & \text { : Kurang } \\
\leq 20 \% & \text { : Kurang Sekali }
\end{array}
$$

(Arikunto \& Jabar, 2010:35)

\section{Analisis Lembar Observasi Aktivitas Guru}


$\bar{X}=\frac{\sum X}{N}$

Keterangan :

$\bar{X} \quad$ : Nilai rata-rata

$\sum \mathrm{X} \quad$ : Jumlah seluruh skor

$N \quad$ : Banyaknya subjek

(Sudjana, 2011:109)

Keterangan :

1 = Kurang

$2=$ Cukup

$3=$ Baik

$4=$ Sangat Baik

Adapun perhitungan rentang skala menggunakan rumus sebagai berikut:

$$
\begin{aligned}
& \text { Rentang Skala }=\frac{\text { skor } m x-\text { skor min }}{\text { skor tertinggi }} \\
& =\frac{4-1}{4} \\
& =\frac{3}{4} \\
& =0,75
\end{aligned}
$$

Tabel 1 Kriteria Penilaian Aktivitas Guru

\begin{tabular}{|l|l|}
\hline \multicolumn{1}{|c|}{ Rata - rata } & \multicolumn{1}{c|}{ Kriteria } \\
\hline $1<\bar{X} \leq 1,75$ & Aktivitas Guru Sangat Kurang \\
\hline $1,75<\bar{X} \leq 2,50$ & Aktivitas Guru Cukup \\
\hline $2,50<\bar{X} \leq 3,25$ & Aktivitas Guru Baik \\
\hline $3,25<\bar{X} \leq 4$ & Aktivitas Guru Sangat Baik \\
\hline
\end{tabular}

(Widoyoko, 2017:110)

\section{Analisis Lembar Observasi Aktivitas Peserta Didik}

$\bar{X}=\frac{\sum X}{N}$

333 | JURNAL IKA VOL 8 No. 2 DESEMBER 2020 
Keterangan :

$\bar{X} \quad$ : Nilai rata-rata

$\sum \mathrm{X}$ : Jumlah seluruh skor

$\mathrm{N} \quad$ : Banyaknya subjek

(Sudjana, 2011:109)

Keterangan:

$1=$ Kurang

$2=$ Cukup

$3=$ Baik

$4=$ Sangat Baik

Adapun perhitungan rentang skala menggunakan rumus sebagai berikut:

$$
\begin{aligned}
& \text { Rentang Skala }=\frac{\text { skor } m x-\text { skor } \min }{\text { skor tertinggi }} \\
& =\frac{4-1}{4} \\
& =\frac{3}{4} \\
& =0,75
\end{aligned}
$$

Tabel 2 Kriteria Penilaian Aktivitas Peserta Didik

\begin{tabular}{|l|l|}
\hline \multicolumn{1}{|c|}{ Rata - rata } & \multicolumn{1}{c|}{ Kriteria } \\
\hline $1<\bar{X} \leq 1,75$ & Aktivitas Guru Sangat Kurang \\
\hline $1,75<\bar{X} \leq 2,50$ & Aktivitas Guru Cukup \\
\hline $2,50<\bar{X} \leq 3,25$ & Aktivitas Guru Baik \\
\hline $3,25<\bar{X} \leq 4$ & Aktivitas Guru Sangat Baik \\
\hline
\end{tabular}

(Widoyoko, 2017:110)

\section{Lembar Angket}

$\bar{X}=\frac{\sum X}{N}$ 
Keterangan :

$\bar{X} \quad$ : Nilai rata-rata

$\sum \mathrm{X} \quad$ : Jumlah seluruh skor

$N \quad$ : Banyaknya subjek

(Sudjana, 2011:109)

1) Catatan:

a) Skor maksimum 2 (skor maksimal setiap indikator)

b) Jumlah pernyataan sebanyak 20 item yang dibagikan kepada 28 peserta didik

c) Skor total adalah 40

2) Kriteria penilaian angket antara lain:

Iya : (pertanyaan positif bernilai 2 dan pertanyaan negatif bernilai 1)

Tidak : $\quad$ (pernyataan positif bernilai 1 dan pernyataan negatif bernilai 2)

(Sunarti dan Rahmawati, 2014:52)

Rentang Skala $=\frac{\text { skor mx-skor min }}{\text { skor tertinggi }}$

$$
\begin{aligned}
& =\frac{2-1}{2} \\
& =\frac{1}{2} \\
& =0,5
\end{aligned}
$$

Jadi, kriteria analisis aktivitas guru dapat dilihat pada tabel berikut ini:

Tabel 3 Kriteria Analisis Angket Sikap Peduli Lingkungan

\begin{tabular}{|l|l|}
\hline \multicolumn{1}{|c|}{ Rata - rata } & \multicolumn{1}{c|}{ Kriteria } \\
\hline $1,0<\bar{X} \leq 1,5$ & Cukup \\
\hline $1,5<\bar{X} \leq 2,0$ & Baik \\
\hline
\end{tabular}

HASIL PENELITIAN DAN PEMBAHASAN 
Penelitian ini dilaksanakan di kelas IV MI Muhammadiyah Limbangan. Subyek penelitian adalah seluruh peserta didik kelas IV yang berjumlah 21 peserta didik yang terdiri dari 8 peserta didik perempuan dan 13 peserta didik laki-laki. Sebelum dilakukan tindakan, peneliti melakukan observasi pembelajaran untuk melihat bagaimana sikap peduli lingkungan peserta didik. Berdasarkan pengamatan sebelum dilakukan tindakan, peserta didik terlihat kurang antusias dan tidak memperhatikan dalam pembelajaran IPA. Hal ini dikarenakan peserta didik jarang diberi kesempatan untuk bertanya dan mengaitkan materi IPA dengan pengalamannya atau lingkungan sekitar. Peserta didik juga kurang diberi kesempatan untuk melakukan praktek langsung sehingga cenderung ramai dan bermain sendiri ketika pembelajaran berlangsung. Adapun hasil observasi pembelajaran di kelas IV dalam pembelajaran IPA adalah sebagai berikut. 1) Pendekatan yang digunakan guru adalah pendekatan teacher centered sehingga guru mendominasi pembelajaran dan peserta didik kurang aktif. 2)Metode yang digunakan adalah metode ceramah dan tanya jawab. 3)Peserta didik selama proses pembelajaran kurang berkonsentrasi dengan penjelasan guru. 4)Peserta didik membuang sampah di lantai ataupun laci meja. 5) Banyak sampah kertas, plastik serta debu atau tanah di lantai kelas. Fakta tersebut dapat dilihat pada gambar di bawah ini. 6) Guru belum menanamkan sikap peduli lingkungan selama pembelajaran berlangsung. 7) Saat guru menjelaskan materi, beberapa peserta didik malah mencoret-coret kertas atau meja dengan coretan yang tidak berhubungan dengan pembelajaran yang sedang berlangsung. prestasi belajar peserta didik di kelas IV MI Muhammadiyah Limbangan juga masih rendah. Perolehan hasil belajar peserta didik pada Ulangan Harian pada mata pelajaran IPA yang kurang maksimal, dan tidak mencapai Kriteria Ketuntasan Minimal (KKM) yang telah ditentukan. Perolehan dari jumlah peserta didik 21 orang,yang mencapai ketuntasan hanya hanya 13 orang dengan persentase $61 \%$ dan tidak mencapai ketuntasan yaitu 8 orang dengan persentase $39 \%$. Ketuntasan tersebut dilihat dari KKM yang ditentukan oleh guru kelas tersebut, yaitu 70. Hal tersebut menunjukkan perlu diperbaiki agar tidak menjadi permasalahan dalam hasil prestasi belajar.

Berdasarkan hasil angket pratindakan dapat diketahui bahwa sebanyak 13 peserta didik (62\%) berada pada kriteria baik dan sisanya 8 peserta didik (38\%) berada pada kriteria cukup. Berdasarkan hasil angket pratindakan, juga dapat diketahui pencapaian setiap indikator sikap peduli lingkungan peserta didik kelas IVA MI Muhammadiyah Limbangan sebagai berikut ini.

\section{Tabel 4.Pencapaian Setiap Indikator Sikap Peduli Lingkungan}




\begin{tabular}{|r|l|l|l|}
\hline No & \multicolumn{1}{|c|}{ Indikator } & Rata-rata & \multicolumn{1}{|c|}{ kriteria } \\
\hline 1. & Menjaga lingkungan kelas dan sekolah & 1,6 & Baik \\
\hline 2. & Memelihara tumbuhan dengan baik & 1,5 & Cukup \\
\hline 3. & Mendukung program go green (penghijauan di sekolah) & 1,3 & Cukup \\
\hline 4. & $\begin{array}{l}\text { Tersedianya tempat untuk membuang sampah organik } \\
\text { dan sampah non organik }\end{array}$ & 1,4 & Cukup \\
\hline 5. & $\begin{array}{l}\text { Menyediakan kamar mandi, air bersih, dan tempat cuci } \\
\text { tangan }\end{array}$ & 1,5 & Cukup \\
\hline
\end{tabular}

Berdasarkan hasil angket, dapat diketahui bahwa tiap indikator secara klasikal berada pada kriteria "cukup" dengan rata-rata 1,4 dan persentase $71 \%$. Berdasarkan data tersebut, data sikap peduli lingkungan peserta didik dapat disajikan dalam bentuk gambar sebagai berikut:

Tabel 5. Rekapitulasi Hasil Angket Sikap Peduli Lingkungan

\begin{tabular}{|c|c|c|c|c|}
\hline No & Kriteria & $\begin{array}{l}\text { Pra Tindakan siklus } \\
\text { Jumlah Peserta Didik }\end{array}$ & $\begin{array}{c}\text { Siklus II } \\
\text { Jumlah Peserta Didik }\end{array}$ & $\begin{array}{c}\text { Siklus I } \\
\text { Jumlah Peserta Didik }\end{array}$ \\
\hline 1. & Baik & 13 & 16 & 19 \\
\hline 2. & cukup & 8 & 5 & 2 \\
\hline
\end{tabular}

Hasil menunjukkan bahwa sikap peduli lingkungan peserta didik mengalami perubahan dari pra tindakan, siklus I sampai siklus II. Hasil angket yang telah didapat menjadi bukti adanya peningkatan sikap peduli lingkungan peserta didik. Hasil peningkatan sikap peduli lingkungan dapat disajikan dalam gambar berikut:

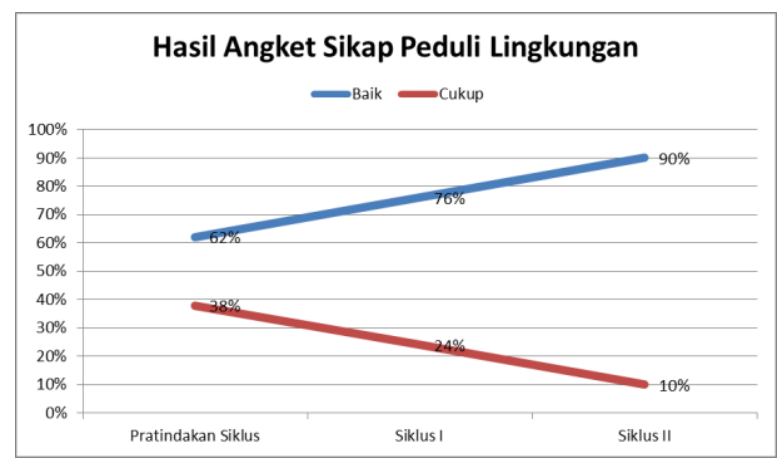

Gambar 1 Hasil Angket Sikap Peduli Lingkungan 
Gambar 1 menunjukkan pencapaian sikap peduli lingkungan peserta didik yang meningkat pada tiap siklus. Hasil angket tahap sebelum tindakan menunjukkan sebanyak 13 peserta didik berada pada kriteria baik dan sisanya 8 peserta didik berada pada kriteria cukup. Siklus I menunjukkan ada sebanyak 16 peserta didik berada pada kriteria baik dan sisanya 5 peserta didik berada pada kriteria cukup. Siklus II menunjukkan ada 2 orang peserta didik berada pada kriteria cukup dan sisanya sebanyak 19 peserta didik berada pada kriteria baik. Peningkatan jumlah peserta didik yang mendapatkan kriteria baik dan cukup juga diikuti dengan penurunan jumlah peserta didik yang mendapatkan kriteria cukup.

Pada kondisi awal sebelum penelitian, pembelajaran IPA di kelas IVA MI Muhammadiyah Limbangan masih berpusat pada guru. Peserta didik belum membangun sendiri pengetahuannya karena pembelajaran masih berupa transfer pengetahuan dari guru ke peserta didik. Pembelajaran yang dilakukan guru menyebabkan prestasi belajar peserta didik masih rendah. Keadaan tersebut membuat guru berpikir untuk meningkatkan prestasi belajar IPA dengan menggunakan model pembelajaran yang lebih berpusat pada peserta didik dan dapat membantu peserta didik mengaitkan materi dengan kenyataan di lingkungannya.

Model CTL menurut Nurhadi (Rusman, 2014: 190) merupakan konsep belajar yang dapat membantu guru mengaitkan antara materi yang ada dengan situasi dunia nyata dan mendorong peserta didik membuat hubungan antara pengetahuan yang dimilikinya dengan penerapannya di kehidupan sehari-hari. Dari pendapat tersebut, dapat dilihat bahwa model pembelajaran Contextual Teaching and Learning (CTL) dirasa tepat untuk meningkatkan prestasi belajar IPA. Model pembelajaran Contextual Teaching and Learning (CTL) dapat membantu peserta didik lebih mudah memahami materi IPA karena pembelajarannya menekankan kegiatan mengaitkan materi IPA dengan pengalaman secara langsung yang terjadi sehari-hari di sekitar peserta didik.

Penerapan model pembelajaran Contextual Teaching and Learning (CTL) dalam pembelajaran harus sesuai dengan 7 asas pokok CTL. Menurut menurut Rusman (2014: 192 ketujuh tahap CTL adalah konstruktivisme (Constructivism), bertanya (Questioning), menemukan (Inquiry), masyarakat belajar (learning community), pemodelan (modelling), dan penilaian sebenarnya (authentic assessment).

Pada siklus II prestasi belajar IPA lebih meningkat dibandingkan pada siklus I. Hal ini ditunjukkan dengan kenaikan nilai rata-rata kelas dari 71 pada siklus I meningkat menjadi 75 pada siklus II. Persentase peserta didik yang mencapai KKM juga meningkat dari $72 \%$ menjadi 81\%. Model pembelajaran Contextual Teaching and Learning (CTL) pada siklus II lebih efektif dibandingkan pada siklus I karena guru telah menerapkan tahapan model CTL dengan beberapa perbaikan berdasarkan refleksi siklus I. Hasil peningkatan prestasi belajar peserta didik yang dapat diketahui setiap akhir siklus, dapat dilihat dalam tabel rekapitulasi hasil prestasi belajar peserta didik di bawah ini: 
Tabel 6 Perbandingan Hasil Evaluasi Pembelajaran IPA Tindakan Siklus I, dan Tindakan Siklus II

\begin{tabular}{|l|l|l|}
\hline \multicolumn{1}{|c|}{ Keterangan } & \multicolumn{1}{|c|}{ Siklus I } & Siklus II \\
\hline Jumlah Peserta Didik & 21 & 21 \\
\hline Rata-Rata & 71 & 75 \\
\hline Presentase Ketuntasan & $72 \%$ & $81 \%$ \\
\hline Kriteria & Baik & $\begin{array}{l}\text { Sangat } \\
\text { Baik }\end{array}$ \\
\hline Nilai Tertinggi & 85 & 95 \\
\hline Nilai Terendah & 55 & 60 \\
\hline Jumlah Nilai & 2965 & 3145 \\
\hline
\end{tabular}

Dari data tersebut persentase peserta didik yang mencapai nilai $\mathrm{KKM} \geq 70$ juga sudah lebih dari $75 \%$. Perbandingan prestasi belajar antara sebelum tindakan, tindakan siklus I dan siklus II dapat dilihat pada gambar berikut ini.

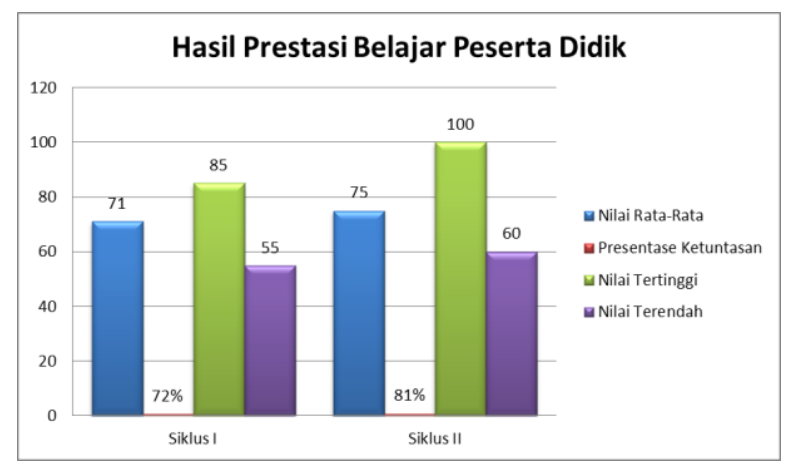

Gambar 2 Hasil Prestasi Belajar Peserta Didik

Gambar 4.6 menunjukkan bahwa nilai rata-rata kelas setelah dilakukan tindakan mengalami peningkatan dari 71 pada siklus I dan 75 pada siklus II. Persentase peserta didik yang mencapai KKM juga mengalami peningkatan dari kondisi awal sebelum tindakan $61 \%$ menjadi $72 \%$ pada siklus I dan $81 \%$ pada siklus II. Hasil penelitian dan pembahasan yang dipaparkan di atas membuktikan bahwa model pembelajaran Contextual Teaching and Learning (CTL) dapat meningkatkan sikap peduli lingkungan prestasi belajar peserta didik kelas IVA MI Muhammadiyah Limbangan.

\section{SIMPULAN DAN SARAN}


Hasil penelitian menunjukkan penerapan model pembelajaran Contextual Teaching and Learning (CTL) pada siklus I dapat meningkatkan dapat meningkatkan sikap peduli lingkungan peserta didik kelas IV MI Muhammadiyah Limbangan pada tema 7 Indahnya Keberagaman di Negeriku. Peran guru dalam menanamkan sikap peduli lingkungan dengan memberi contoh, teguran, dan pengkondisian kepada peserta didik sehingga mengenai memisahkan dan membuang sampah organik dan non organik dengan tepat, kebersihan kelas dan kamar mandi sudah terjaga dengan keefektifan jadwal piket yang dilaksanakan, terpelihara tumbuhan di sekolah. Guru akan menegur peserta didik yang kurang antusias saat melakukan pencapaian tiap indikator sikap peduli lingkungan. Guru juga mengkondisikan lingkungan berupa dengan penempelan berbagai poster seperti tata cara cuci tangan yang baik dan benar, cara membuang sampah ornganik dan non organik, slogan tentang merawat bumi.

Penerapan model pembelajaran contextual teaching and learning (CTL) dapat meningkatkan prestasi belajar peserta didik kelas IV MI Muhammadiyah Limbangan pada tema 7 Indahnya Keberagaman di Negeriku. Hal tersebut ditunjukkan dari perolehan rata-rata nilai siklus I yaitu 71 dengan ketuntasan belajar 72\% dan meningkat menjadi 75 dengan ketuntasan belajar $81 \%$ pada siklus II sehingga indikator keberhasilan penelitian tercapai.

\section{DAFTAR PUSTAKA}

Adisusilo, Sutarjo. 2014. Pembelajaran Nilai-Karakter: Konstruktivisme dan VCT sebagai Inovasi Pendekatan Pembelajaran Afektif. Jakarta: Rajawali Press.

Anggraeni, Sugiyo dan Kustiono. 2017. The Difference of Ability to Ask, Scientific Attitude, Motivation Before and After Following Contextual Teaching and Learning Model. Journal of Primary Education. Semarang. Universitas Negeri Semarang.

Arifin,Zainal. 2013. Evaluasi Pembelajaran . Bandung: Remaja Rosdakarya.

Arikunto, S. C, Jabar. 2010. Evaluasi Program Pendidikan. Jakarta: Bumi. Aksara.

Arikunto, S. Suhardjono dan Supardi. 2008. Penelitian Tindakan Kelas. Jakarta: Bumi Aksara.

Aunurrahman. 2010. Buku dan Pembelajaran. Bandung: Alfabeta.

Badarudin. 2018. Peningkatan Sikap Peduli Lingkungan dan Prestasi Belajar IPA menggunakan Model Problem Based Learning Berbasis Literasi pada Subtema Lingkungan Tempat Tinggalku di Kelas IV MI Muhammadiyah Kramat. Jurnal Pendidikan Dasar Indonesia. Purwokerto.Universitas Muhammadiyah Purwokerto.

Erwin, Muhammad. 2009. Hukum Lingkungan Dalam Sistem Kebijaksanaan Pembangunan Lingkungan Hidup. Bandung: Refika Aditama

Fitri, Agus Zaenul. 2017. Pendidikan Karakter Berbasis Nilai \& Etika di Sekolah. Jogjakarta: Ar-Ruzz Media.

340 | JURNAL IKA VOL 8 No. 2 DESEMBER 2020 
Kunandar. 2011. Langkah Mudah Penelitian Tindakan Kelas: Sebagai Pengembangan Profesi Guru. Jakarta: Raja Grafindo Persada.

Mulyasa. 2014. Pengembangan dan Implementasi Kurikulum 2013. Bandung: Remaja Rosdakarya.

Narwanti, Sri. 2011. Pendidikan karakter. Yogyakarta : Familia

Purwanto, Ngalim. 2010. Prinsip-prinsip dan Teknik Evaluasi Pengajaran. Bandung: PT. Remaja Rosdakarya

Rahmawati, Subali dan Sarwi. 2019. The Effect of Ethnoscience Based Contextual Learning Toward Students' Learning Activity. Journal of Primary Education. Semarang. Universitas Negeri Semarang 